\title{
Residues of Ethoprop and Disulfoton in Soils and Flue-cured Tobacco*
}

\author{
by R. B. Leidy and T. J. Sbeets \\ Pesticide Residue Researd Laboratory, North Carolina State University, \\ Raleigh, North Carolina, U.S.A.
}

\section{INTRODUCTION}

Ethoprop [O-ethyl S,S-dipropyl phosphorodithioate] is a non-systemic, non-fumigant nematicide and soil insecticide which has been registered since 1967 for use on tobacco in the United States. Disulfoton [O,O-diethyl S(2-(ethylthio)ethyl) phosphorodithioate] is a systemic acaricide and insecticide used for soil application to protect tobacco plants from insect attack. This compound received a label for tobacco use in 1970. Disulfoton has been shown to persist in soils for at least 4 weeks (1), and the sulfone analog persists for more than 64 days (2). Disulfoton is metabolized by soil microorganisms to its sulfone and sulfoxide analogs, the rate depending on soil type, moisture, humidity and temperature. Disulfoton and the metabolites are absorbed and translocated in plants where further metabolism takes place (3). Few data are available in the literature on residues of ethoprop in either soils or flue-cured tobacco.

Bowman et al. (4) found that residues of disulfoton metabolites in flue-cured tobacco from the second harvest varied from $0.82 \mathrm{ppm}$ for the oxygen analog sulfoxide to 23.7 ppm for the sulfone. U.S. flue-cured tobacco samples sent to the Federal Republic of Germany in 1973 and analyzed for various insecticides contained ethoprop residues of 0.01 and $0.03 \mathrm{ppm}$ and total disulfoton residues of 0.4 and $0.9 \mathrm{pPm}(5)$.

This study was conducted to determine residue levels of ethoprop and disulfoton in flue-cured tobacco grown in ethoprop and disulfoton-treated soil.

\section{MATERIALS AND METHODS}

\section{Insecticide Application and Sampling}

Experiments were established in 1976 on Norfolk sandy loam on the Central Crops Researdh Station near Clayton, N. C., and on a Cecil sandy loam on the Upper Piedmont Research Station near Reidsville, N. C. Cultural practices

\footnotetext{
- Paper No. 5916 of the Journal Series of North Carolina Agricultural Research Service, Raleigh, Nortb Caroliaa, U.S.A.

Use of brand names in this publication does not imply endorsement of the products named or eriticisn of similar ones not mentioned.

Received: 16th May 1979- aceepted: 27th September 1979.
}

suggested by the North Carolina Cooperative Extension Service were followed. Ethoprop ${ }^{+}$was applied April 6 at Clayton and May 7 at Reidsville at rates of 6.72 and $13.4 \mathrm{~kg} \mathrm{a}: \mathrm{i} .++/ \mathrm{ha}$. A combination treatment of $6.72 \mathrm{~kg}$ a.i./ha of ethoprop plus $3.36 \mathrm{~kg}$ a.i./ha of disulfoton was included to represent a common agricultural practice. Disulfoton ${ }^{+}$was applied broadcast on the same dates at rates of 3.4 and $6.7 \mathrm{~kg}$ a.i./ha, then incorporated with the disk set to cut about 12 to $15 \mathrm{~cm}$ deep. Plots were four rows wide and $14 \mathrm{~m}$ long. There were four border rows between plots. Rows were spaced $1.14 \mathrm{~m}$. There were four replications. Speight variety G-28 was transplanted April 22 at Clayton and May 12 at Reidsville.

Soil samples were taken approximately 3 weeks after transplanting and monthly thereafter from each location. Sixteen cores $(15$ by $2.5 \mathrm{~cm}$ ) were collected from the center $10 \mathrm{~m}$ of the middle two rows of each plot and were placed in a plastic bag. The middles between rows were avoided during sampling. The samples were packed in solid carbon dioxide, transported to the laboratory, and stored at $-18^{\circ} \mathrm{C}$ until analyzed.

Tobacco was harvested four times at Clayton and five times at Reidsville; the first harvest was taken approximately 12 weeks after transplanting at Clayton and 10 weeks after transplanting at Reidsville. The leaf samples were removed by hand at the normal harvest time from the same area in the plot as the soil samples. The tobacco was cured in conventional barns. After curing, the samples were placed in plastic bags and transported to the laboratory. Samples were ground in a Wiley mill and thoroughly mixed, and a 0.5 -liter subsample was saved for analysis. Subsamples were stored at $-18^{\circ} \mathrm{C}$.

\section{Soil Analyses}

For analysis of ethoprop, $20 \mathrm{~g}$ of sifted soil were weighed into a tared $475 \mathrm{ml}$ glass jar and $75 \mathrm{ml}$ of chloroform were added. The samples were shaken mechanically for $15 \mathrm{~min}$. Extracts were filtered through $50 \mathrm{~g}$ of anhydrous sodium sulfate into $500 \mathrm{ml}$ flasks. After an additional $75 \mathrm{ml}$ of chloroform was added, the soil was extracted for an ad-

\footnotetext{
+ Formulations of pesticides: ethoprop, Mocap to G; disulfoton, Di-Syston $15 \mathrm{G}$.

\# active ingredient.
} 
ditional $15 \mathrm{~min}$; and the suspension was filtered. The filter containing the soil was rinsed with $50 \mathrm{ml}$ of chloroform, and the combined extract was evaporated under vacuum at $45^{\circ} \mathrm{C}$ to 2 to $3 \mathrm{ml}$. Samples were brought to a $10 \mathrm{ml}$ volume with ethyl acetate.

Twenty-five-gram subsamples of sifted soil from plots containing disulfoton were weighed into tared $475 \mathrm{ml}$ glass jars, and $100 \mathrm{ml}$ of ethyl acetate were added to each. The samples were shaken mechanically for $15 \mathrm{~min}$. Extracts were filtered through $50 \mathrm{~g}$ of anhydrous sodium sulfate into $500 \mathrm{ml}$ flasks. An additional $100 \mathrm{ml}$ of ethyl acetate was added, and the soil was extracted for an additional $15 \mathrm{~min}$. The suspension was filtered, and the filter containing the soil was rinsed with $50 \mathrm{ml}$ of ethyl acetate. The combined extract was evaporated under vacuum at $45^{\circ} \mathrm{C}$ to 2 to $3 \mathrm{ml}$ and brought to a $10 \mathrm{ml}$ volume with ethyl acetate.

\section{Tobacco Analyses}

Fifteen grams of ground tobacco containing ethoprop were weighed into a Soxhlet thimble and extracted 3 hours with $150 \mathrm{ml}$ of hexane at 10 turnovers per hour. The hexane extract was evaporated to 5 to $8 \mathrm{ml}$ under vacuum at $45^{\circ} \mathrm{C}$ and transferred to a glass column ( 20 by $2.5 \mathrm{~cm}$ ) containing $20 \mathrm{~g}$ of deactivated Florisil ( $5 \%$ water) topped with $2.5 \mathrm{~cm}$ layer of sodium sulfate. Fifty milliliters of hexane were added and allowed to drain; then $100 \mathrm{ml}$ of ethyl acetate were added to the column to elute the ethoprop. The column eluate containing the ethoprop was evaporated to 1 to $2 \mathrm{ml}$ in a rotary evaporator; the extract was diluted to $10 \mathrm{ml}$ with ethyl acetate and analyzed by gas-liquid chromatography (GLC).

Ten grams of ground tobacco containing disulfoton were placed in a Soxhlet thimble and extracted 4 hours with $250 \mathrm{ml}$ of ethyl acetate. The extract was cooled and poured directly into a glass column ( 20 by $2.5 \mathrm{~cm}$ ) containing, from bottom to top, $5 \mathrm{~cm}$ of anhydrous sodium sulfate, $20 \mathrm{~g}$ of $5 \%$ deactivated Florisil, and another $5 \mathrm{~cm}$ of anhydrous sodium sulfate. The column was pre-rinsed with $50 \mathrm{ml}$ of hexane. The eluate was concentrated to 2 to $3 \mathrm{ml}$ under vacuum at $45^{\circ} \mathrm{C}$ and diluted to $10 \mathrm{ml}$ with ethyl acetate.

\section{Gas Chromatography and Recovery}

The gas chromatograph was either a Tracor MT 220 or Tracor Model 222 equipped with a flame photometric detector (FPD) operated in the phosphorus mode. The FPD on the Tracor Model 222 dromatograph has had the stainless steel base replaced by an aluminum bracket and utilizes a stainless steel capillary transfer line connected between the column exit port and the flame base. The two other flame photometric detectors in this laboratory were modified to reflect these changes. The column used for soil residues of ethoprop was $183.0 \mathrm{~cm}$ by $6.4 \mathrm{~mm}$ inside diameter $U$-shaped glass containing $4 \% \mathrm{SE}-30+6 \%$ $\mathrm{QF}-1$ on GasChrom Q (80/100). Because of an interference peak, a $183.0 \mathrm{~cm}$ by $6.4 \mathrm{~mm}$ inside diameter column padked with 5\% Carbowax $20 \mathrm{M}$ on GasChrom Q (60/80) was used for tobacco extracts. Temperatures were: oven, $180^{\circ} \mathrm{C}$ for soil, $195^{\circ} \mathrm{C}$ for tobacco; detector, $195^{\circ} \mathrm{C}$ for soil and tobacco; and inlet port, $200^{\circ} \mathrm{C}$ for both soil and tobacco. Nitrogen was the carrier gas, and flow rates were $120 \mathrm{ml} / \mathrm{min}$ for soils and $110 \mathrm{ml} / \mathrm{min}$ for tobacco. Gases to the detector were hydrogen and air at flow rates of 50 and $80 \mathrm{ml} / \mathrm{min}$, respectively. Data were quantitated by the peak height method.

Disulfoton residues from soil and tobacco samples were determined on a $122.0 \mathrm{~cm}$ by $2.0 \mathrm{~mm}$ inside diameter U-shaped glass column containing $10 \%$ OV-101 on Supelcoport $(80 / 100)$. Temperatures were: oven, $170^{\circ} \mathrm{C}$; detector, $190^{\circ} \mathrm{C}$; and inlet, $200^{\circ} \mathrm{C}$. Nitrogen was the carrier gas with a flow rate of $60 \mathrm{ml} / \mathrm{min}$. Gases to the detector were hydrogen and air at flow rates of 200 and $100 \mathrm{ml} / \mathrm{min}$, respectively.

The efficiency of the analytical method was determined by adding known amounts of ethoprop or disulfoton and its metabolites to untreated soil and tobacco and analyzing the fortified samples by the same method. Two fortified samples were analyzed with each set of 16 unknown samples. Residues of disulfoton and its metabolites were calculated by triangulation, and calibration curves of peak area versus the amounts of each component were constructed.

\section{RESULTS AND DISCUSSION}

Chromatograms of ethoprop in soil and tobacco were relatively free of interferences (Fig. 1). Figure 2 shows the mixed standard of disulfoton, its oxygen analog, the oxygen analog of disulfoton sulfoxide, and disulfoton sulfone. Typical chromatograms of these compounds in soil and tobacco samples are shown in Figures 3 and 4, respectively. It can be seen from these three figures that the longer retention times of the sulfoxide oxygen analog and sulfone metabolites made data calculation by triangulation a necessity.

\section{Flgure 1. Chromatograms of ethoprop in soil and tobacco.}

A. Ethoprop standard (containing $0.2 \mu \mathrm{g} / \mathrm{ml}$ ) chromatographed on $4 \%$ SE-30 + $6 \%$ QF-1 column.

B. Soll sample contalning $1.03 \mathrm{ppm}$ ethoprop (application rate: $13.4 \mathrm{~kg}$ a.i./ha; 1st sampling).

C. Ethoprop standard (containing $0.2 \mu \mathrm{g} / \mathrm{ml}$ ) chromatographed on $5.0 \%$ Carbowax $20 \mathrm{M}$ column.

D. Tobacco sample containing $0.08 \mathrm{ppm}$ (appllcation rate: $13.4 \mathrm{~kg}$ a.i./ha; 1st harvest).

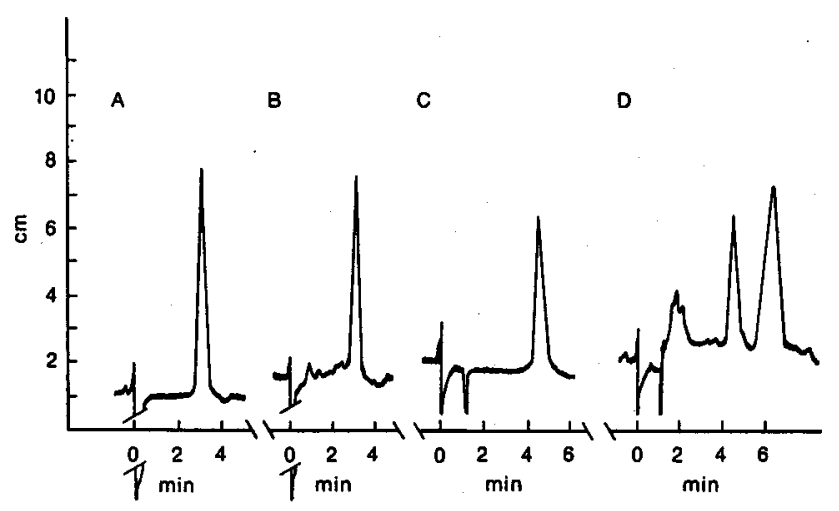


Figure 2. Chromatogram of analytical standards of dl-

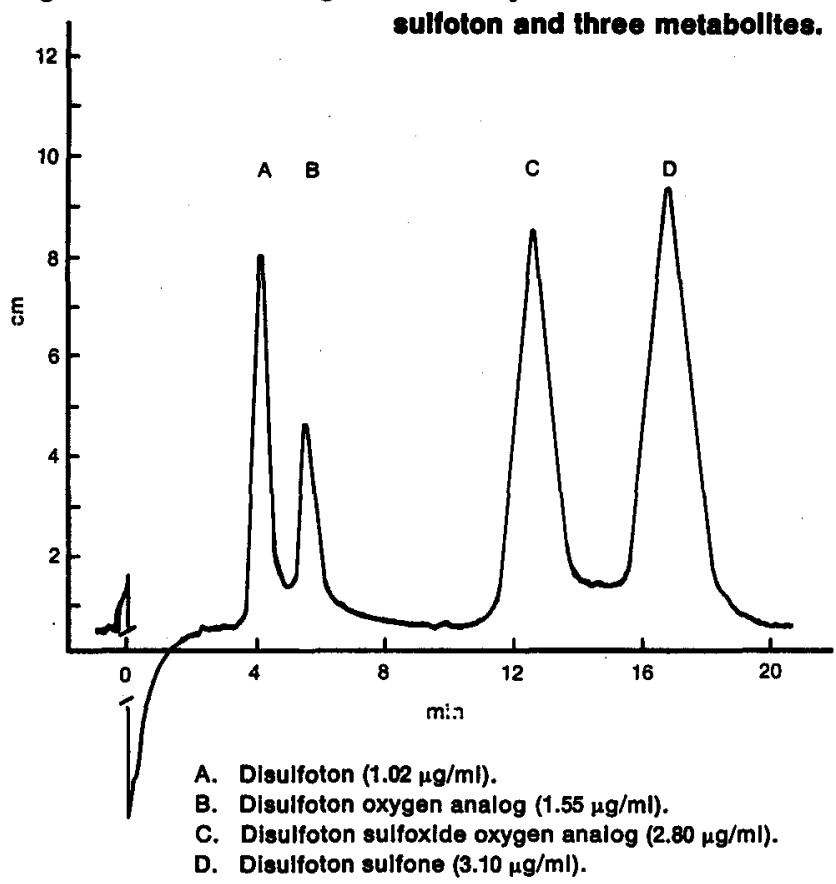

The average recoveries of ethoprop were 82 percent from soil and 85 percent from tobacco at spiking levels of 1 to $100 \mathrm{ppm}$ in soil and 0.01 to $20 \mathrm{ppm}$ in tobacco (Table 1). The lowest detectable limit was $0.01 \mathrm{ppm}$. Recoveries of disulfoton and 5 metabolites from untreated soil are shown in Table 2. Within each component the recoveries of varying amounts were consistent. The poorest recovery from soil was the disulfoton oxygen analog, averaging 66 percent from added amounts varying between 0.01 and $0.8 \mathrm{ppm}$. Disulfoton and the sulfone had the highest recoveries, averaging 86 and 84 percent, respectively.

Table 3 shows recoveries of known amounts of disulfoton and 5 metabolites from flue-cured tobacco. As was seen with the data from soil, recoveries of the oxygen analogs

Figure 3. Chromatograms of three metabolites of disulfoton extracted from soll (application rate: $6.7 \mathrm{~kg} \mathrm{a} . \mathrm{l} . / \mathrm{ha}$,

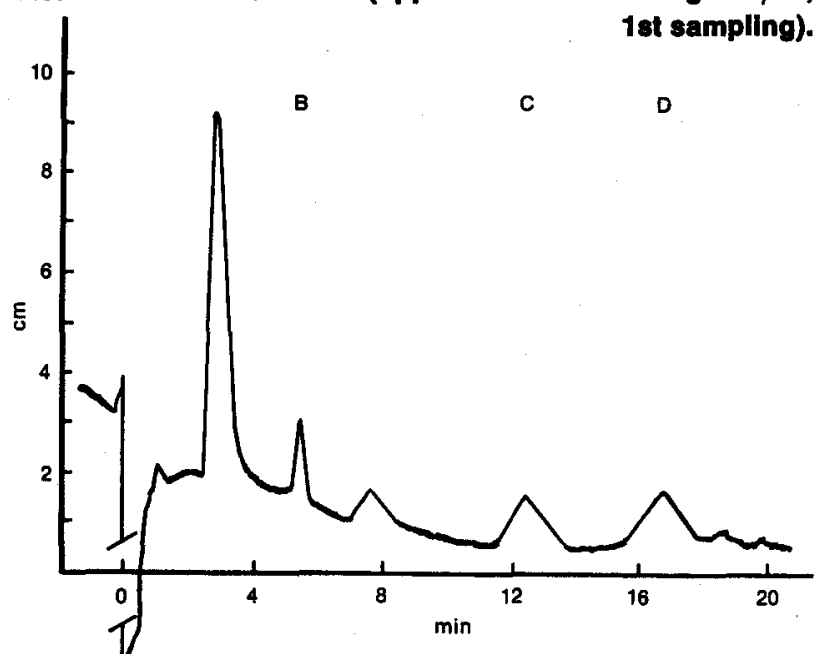

B. Disulfoton oxygen analog (0.01 ppm).

C. Disulfoton sulfoxide oxygen analog $(0.09 \mathrm{ppm})$.

D. Disulfoton sulfone (0.01 ppm).
Table 1. Recoveries of known amounts of ethoprop added to untreated soll or flue-cured tobacco*.

\begin{tabular}{|c|c|c|c|c|}
\hline Sample type & $\begin{array}{l}\text { Amount } \\
\text { added } \\
\text { (ppm) }\end{array}$ & $\begin{array}{c}\text { Number } \\
\text { of } \\
\text { samples }\end{array}$ & $\begin{array}{c}\text { Range } \\
(\%)\end{array}$ & $\begin{array}{c}\text { Average } \\
\text { recovery } \\
(\%)\end{array}$ \\
\hline \multirow[t]{5}{*}{ Soil } & 1 & 5 & $77-90$ & 81 \\
\hline & 5 & 4 & $83-94$ & 91 \\
\hline & 10 & 5 & $70-90$ & 82 \\
\hline & 25 & 2 & $78-81$ & 80 \\
\hline & 100 & 2 & $69-79$ & 74 \\
\hline \multirow[t]{13}{*}{ Tobacco } & 0.01 & 2 & $70-80$ & 75 \\
\hline & 0.05 & 2 & $84-88$ & 86 \\
\hline & 0.1 & 4 & $84-100$ & 93 \\
\hline & 0.2 & 1 & & 92 \\
\hline & 0.3 & 1 & & 90 \\
\hline & 0.5 & 1 & & 67 \\
\hline & 1.0 & 2 & $70-87$ & 79 \\
\hline & 1.5 & 1 & & 85 \\
\hline & 2.5 & 1 & & 97 \\
\hline & 3.0 & 2 & $78-85$ & 82 \\
\hline & 5.0 & 3 & $82-86$ & 84 \\
\hline & 10.0 & 3 & $69-87$ & 79 \\
\hline & 20.0 & 1 & & 93 \\
\hline
\end{tabular}

- Amounts shown were added to $20 \mathrm{~g}$ of untreated soll or $15 \mathrm{~g}$ of untreated tobacco. Recoveries based on equivalent amounts added to conical tubes and brought to $10 \mathrm{ml}$ with ethyl acetate.

of disulfoton and disulfoton sulfoxide were lower than the other compounds. However, the average recoveries of all compounds were higher from untreated tobacco compared to untreated soil.

Ethoprop levels for the first sampling of soil taken about 30 days after application were approximately the same for corresponding treatments at the two locations (Table 4). The $13.4 \mathrm{~kg} / \mathrm{ha}$ application rate averaged $1.13 \mathrm{ppm}$ over locations, compared to $0.54 \mathrm{ppm}$ for the $6.72 \mathrm{~kg} / \mathrm{ha}$ rate. Data for subsequent samplings showed marked dif-

Figure 4. Chromatogram of disulfoton and three metabolites extracted from flue-cured tobacco (appllcation rate: $6.7 \mathrm{~kg}$ a. I./ha, tst harvest).

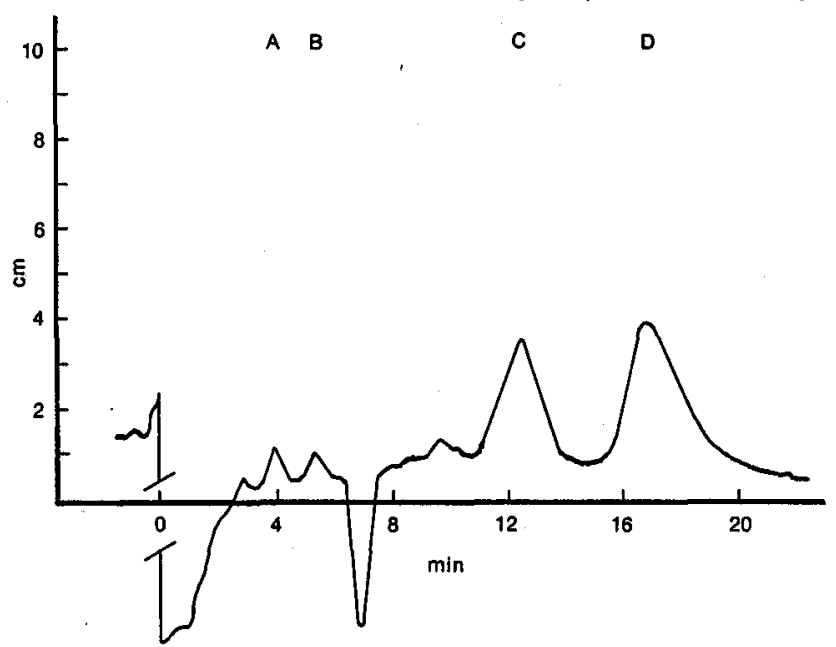

A. Disultoton (0.03 ppm)

B. Disulfoton oxygen analog (0.04 ppm).

C. Disulfoton sulfoxide oxygen analog $(0.56 \mathrm{ppm})$

D. Disulfoton aulfone (1.23 ppm). 
Table 2. Recoverles of known amounts of disulfoton and flve metabolites added to untreated soll ".

\begin{tabular}{|c|c|c|c|c|}
\hline Compound & $\begin{array}{l}\text { Amount } \\
\text { added } \\
\text { (ppm) }\end{array}$ & $\begin{array}{c}\text { Number } \\
\text { of } \\
\text { samples }\end{array}$ & $\begin{array}{c}\text { Range } \\
(\%)\end{array}$ & $\begin{array}{c}\text { Average } \\
\text { recovery } \\
(\%)\end{array}$ \\
\hline \multirow[t]{7}{*}{ Disulfoton } & 0.04 & 1 & & 83 \\
\hline & 0.05 & 2 & $89-98$ & 94 \\
\hline & 0.75 & 2 & $74-81$ & 78 \\
\hline & 1.00 & 2 & $86-87$ & 87 \\
\hline & 2.00 & 2 & $84-88$ & 86 \\
\hline & 3.00 & 2 & 89-93 & 91 \\
\hline & 5.00 & 3 & $81-94$ & 85 \\
\hline \multirow{6}{*}{$\begin{array}{l}\text { Disulfoton } \\
\text { oxygen analog }\end{array}$} & 0.01 & 4 & $65-88$ & 71 \\
\hline & 0.02 & 2 & 65 & 65 \\
\hline & 0.05 & 2 & $64-65$ & 65 \\
\hline & 0.10 & 2 & $66-68$ & 67 \\
\hline & 0.25 & 2 & $63-64$ & 64 \\
\hline & 0.80 & 2 & 63 & 63 \\
\hline \multirow{4}{*}{$\begin{array}{l}\text { Disulfoton } \\
\text { sulfoxide }\end{array}$} & 0.01 & 4 & $80-92$ & 84 \\
\hline & 0.05 & 4 & $78-92$ & 85 \\
\hline & 0.10 & 4 & $78-84$ & 82 \\
\hline & 0.50 & 2 & $76-84$ & 80 \\
\hline \multirow{4}{*}{$\begin{array}{l}\text { Disulfoton } \\
\text { sulfoxide } \\
\text { oxygen analog }\end{array}$} & 0.01 & 4 & $70-78$ & 74 \\
\hline & 0.05 & 4 & $64-74$ & 69 \\
\hline & 0.10 & 4 & $69-73$ & 71 \\
\hline & 0.50 & 2 & $68-72$ & 70 \\
\hline \multirow{4}{*}{$\begin{array}{l}\text { Disulfoton } \\
\text { sulfone }\end{array}$} & 0.04 & 4 & $80-86$ & 83 \\
\hline & 0.10 & 4 & $80-86$ & 83 \\
\hline & 0.25 & 2 & 84 & 84 \\
\hline & 0.40 & 4 & $79-94$ & 87 \\
\hline \multirow{4}{*}{$\begin{array}{l}\text { Disulfoton } \\
\text { sulfone } \\
\text { oxygen analog }\end{array}$} & 0.04 & 4 & $78-81$ & 80 \\
\hline & 0.10 & 4 & $61-82$ & 75 \\
\hline & 0.25 & 2 & $78-82$ & 80 \\
\hline & 0.40 & 4 & $70-82$ & 76 \\
\hline
\end{tabular}

- Amounts shown were added to $25 \mathrm{~g}$ untreated soll. Recoveries based on equivalent amounts added to conical tubes and brought to $10 \mathrm{ml}$ with ethyl acetate.
Table 3. Recoverles of known amounts of disulfoton and five metabolites added to untreated flue-cured tobacco*.

\begin{tabular}{|c|c|c|c|c|}
\hline Compound & $\begin{array}{c}\text { Amount } \\
\text { added } \\
\text { (ppm) }\end{array}$ & $\begin{array}{c}\text { Number } \\
\text { of } \\
\text { samples }\end{array}$ & $\begin{array}{c}\text { Range } \\
(\%)\end{array}$ & $\begin{array}{c}\text { Average } \\
\text { recovery } \\
(\%)\end{array}$ \\
\hline \multirow[t]{6}{*}{ Disulfoton } & 0.1 & 4 & $78-100$ & 86 \\
\hline & 0.25 & 4 & $82-95$ & 89 \\
\hline & 0.50 & 4 & $90-96$ & 93 \\
\hline & 0.75 & 4 & $82-84$ & 84 \\
\hline & 1.00 & 4 & $83-90$ & 87 \\
\hline & 1.50 & 4 & $81-91$ & 85 \\
\hline \multirow{6}{*}{$\begin{array}{l}\text { Disulfoton } \\
\text { oxygen analog }\end{array}$} & 0.01 & 4 & $80-100$ & 95 \\
\hline & 0.025 & 4 & $50-88$ & 72 \\
\hline & 0.050 & 4 & $63-89$ & 78 \\
\hline & 0.10 & 4 & $92-97$ & 94 \\
\hline & 0.50 & 4 & $74-80$ & 77 \\
\hline & 1.00 & 4 & $76-88$ & 82 \\
\hline \multirow{5}{*}{$\begin{array}{l}\text { Disulfoton } \\
\text { sulfoxide }\end{array}$} & 0.04 & 4 & $51-88$ & 75 \\
\hline & 0.08 & 4 & $83-99$ & 90 \\
\hline & 0.125 & 4 & $84-95$ & 88 \\
\hline & 0.25 & 6 & $84-92$ & 87 \\
\hline & 0.50 & 6 & $83-98$ & 89 \\
\hline \multirow{5}{*}{$\begin{array}{l}\text { Disulfoton } \\
\text { sulfoxide } \\
\text { oxygen analog }\end{array}$} & 0.04 & 4 & $77-89$ & 85 \\
\hline & 0.08 & 4 & $56-78$ & 66 \\
\hline & 0.125 & 4 & $67-83$ & 74 \\
\hline & 0.25 & 6 & $69-87$ & 76 \\
\hline & 0.50 & 6 & $75-85$ & 80 \\
\hline \multirow{5}{*}{$\begin{array}{l}\text { Disulfoton } \\
\text { sulfone }\end{array}$} & 0.01 & 4 & $78-100$ & 89 \\
\hline & 0.025 & 4 & $79-91$ & 85 \\
\hline & 0.05 & 4 & $73-88$ & 78 \\
\hline & 0.10 & 6 & 83-99 & 89 \\
\hline & 0.50 & 6 & $85-98$ & 92 \\
\hline \multirow{5}{*}{$\begin{array}{l}\text { Disulfoton } \\
\text { sulfone } \\
\text { oxygen analog }\end{array}$} & 0.01 & 4 & $66-87$ & 80 \\
\hline & 0.025 & 4 & $80-88$ & 84 \\
\hline & 0.05 & 4 & $77-80$ & 78 \\
\hline & 0.10 & 6 & $75-85$ & 80 \\
\hline & 0.50 & 6 & $75-88$ & 83 \\
\hline
\end{tabular}

- Amounts shown were added to $10 \mathrm{~g}$ untreated flue-cured tobacco. Recoveries based on equivalent amounts added to conical tubes and brought to $10 \mathrm{ml}$ with ethyl acetate.

Table 4. Ethoprop residues in soils taken from two locatlons.

\begin{tabular}{|c|c|c|c|c|}
\hline \multirow[b]{2}{*}{ Location } & \multirow{2}{*}{$\underset{\text { (kg/ha) }}{\text { Rate }}$} & \multicolumn{3}{|c|}{ Sampling * } \\
\hline & & $\begin{array}{c}\text { first } \\
\text { (ppm) }\end{array}$ & $\begin{array}{c}\text { second } \\
\text { (ppm) }\end{array}$ & $\begin{array}{l}\text { third } \\
\text { (ppm) }\end{array}$ \\
\hline \multirow{4}{*}{$\begin{array}{l}\text { Central Crops } \\
\text { Research Station } \\
\text { (Clayton, N.C.) }\end{array}$} & 0.0 & & 0.01 & 0.01 \\
\hline & 6.72 & 0.42 & 0.04 & 0.02 \\
\hline & 13.4 & 0.96 & 0.09 & 0.04 \\
\hline & 6.72 ** & 0.58 & 0.13 & 0.03 \\
\hline \multirow{4}{*}{$\begin{array}{l}\text { Upper Piedmont } \\
\text { Research Station } \\
\text { (Reidsville, N.C.) }\end{array}$} & 0.0 & 0.04 & 0.02 & 0.02 \\
\hline & 6.72 & 0.50 & 0.41 & 0.10 \\
\hline & 13.4 & 1.30 & 0.74 & 0.23 \\
\hline & 6.72 ** & 0.65 & 0.40 & 0.18 \\
\hline
\end{tabular}

- Each value an average of four replications. Solls sampled May 10, June 16, and July 20, 1976 at Central Crops Research Station. Solls sampled June 14, July 16, and August 23, 1976 at Upper Pledmont Research Station. The untreated control plot was not sampled the first time.

* Combination treatment with disulfoton. 
Table 5. Residues of disulfoton and three motabolites in solls from Central Crops (Clayton) and Upper Pledmont (Reldsville) Research Statlons.

\begin{tabular}{l|c|c|c|c}
\hline Disulfoton & \multirow{2}{*}{$\begin{array}{c}\text { or } \\
\text { metabollte }\end{array}$} & $\begin{array}{c}\text { Rate } \\
(\mathrm{kg} / \mathrm{ha})\end{array}$ & \multicolumn{3}{|c}{ Sampling } \\
\cline { 3 - 5 } & $\begin{array}{c}\text { first } \\
(\mathrm{ppm})\end{array}$ & $\begin{array}{c}\text { second } \\
\text { (ppm) }\end{array}$ & $\begin{array}{c}\text { third } \\
(\mathrm{ppm})\end{array}$ \\
\hline
\end{tabular}

Central Crops:

\begin{tabular}{llrrr} 
Disulfoton & 3.4 & 0.02 & 0.02 & 0.02 \\
& 6.7 & 0.03 & 0.02 & 0.02 \\
& $3.4^{* *}$ & 0.02 & 0.01 & $<0.01$ \\
& 3.4 & 0.01 & $<0.01$ & $<0.01$ \\
Disulfoton & 6.7 & $<0.01$ & $<0.01$ & $<0.01$ \\
oxygen analog & $6.4 * *$ & $<0.01$ & $<0.01$ & $<0.01$ \\
& 3.4 & 0.03 & $<0.01$ & $<0.01$ \\
Disulfoton & 3.7 & $<0.01$ & 0.01 & $<0.01$ \\
sulfoxide & $3.4 *$ & $<0.01$ & $<0.01$ & $<0.01$ \\
oxygen analog & 3.4 & 0.18 & 0.02 & 0.02 \\
& & 0.34 & 0.11 & 0.11 \\
Disulfoton & 3.7 & 0.22 & 0.05 & 0.02 \\
sulfone & $3.4 *$ & & & \\
& & & & \\
\hline
\end{tabular}

Upper Pledmont:

$\begin{array}{llrrr}\text { Disulfoton } & 3.4 & 0.02 & <0.01 & <0.01 \\ & 6.7 & 0.02 & <0.01 & <0.01 \\ & 3.4 * * & 0.02 & 0.02 & <0.01 \\ & & & & \\ \text { Disulfoton } & 3.4 & <0.01 & <0.01 & <0.01 \\ \text { oxygen analog } & 6.7 & <0.01 & <0.01 & <0.01 \\ & 3.4 * * & <0.01 & <0.01 & <0.01 \\ & & 0.03 & 0.02 & <0.01 \\ \text { Disulfoton } & 3.4 & 0.02 & <0.01 & <0.01 \\ \text { sulfoxide } & 6.7 & 0.01 & <0.01 & <0.01 \\ \text { oxygen analog } & 3.4^{* *} & <0.1 \\ & & & & \\ \text { Disulfoton } & 3.4 & 0.26 & 0.13 & 0.08 \\ \text { sulfone } & 6.7 & 0.68 & 0.32 & 0.10 \\ & 3.4 * * & 0.19 & 0.07 & 0.03\end{array}$

- Each value an average of four replications. Residues of disulfoton sulfoxide and disulfoton sulfone oxygen analog were below the detectable limit of $0.01 \mathrm{ppm}$. Solls sampled May 10, June 16, and July 20, 1976 at Central Crops Research Station. Solls samples June 14, July 16, and August 23, 1976 at Upper Piedmont Research Station.

** Combination treatment with ethoprop.

ferences in ethoprop residues between locations. Residue levels declined gradually at the Upper Piedmont Research Station; the drop was more rapid at the other location and the concentration was near the low detectable limit at the last sampling.

Residues of disulfoton and the three metabolites found in soil from both locations are shown in Table 5. Small amounts (0.03 ppm or less) of disulfoton, its oxygen analog, and the sulfoxide oxygen analog were found in many of the samples from both locations. Residues of disulfoton sulfone were higher than those for the other three compounds and averaged 0.18 and $0.22 \mathrm{ppm}$, respectively, for the $3.4 \mathrm{~kg} / \mathrm{ha}$ applied alone and in combination with ethoprop at the Central Crops Station. The average was $0.34 \mathrm{ppm}$ for the $6.7 \mathrm{~kg} / \mathrm{ha}$ rate. Corresponding residue levels for the Reidsville location were 0.26 , 0.19 , and $0.68 \mathrm{ppm}$. Total residues (disulfoton plus meta- bolites) in soil were greater at the Upper Piedmont Station than from the Central Crops Station over the three sampling periods. These data are similar to those for ethoprop plots included in the same experiment (Table 3 ).

At Clayton $12.1 \mathrm{~cm}$ of rain fell in June and $1.1 \mathrm{~cm}$ during July compared to $13.0 \mathrm{~cm}$ in June and $7.7 \mathrm{~cm}$ (rainfall plus irrigation) in July at the Upper Piedmont Research Station. Moisture percentages were higher in soil from the Upper Piedmont Station than in that from the Central Crops Research Station at all three sampling times. At the second and third samplings, there was a 5 and 10 fold difference, respectively. The difference in soil moisture level may have affected the persistence of the insecticides; however, most pesticides persist longer in dry soils than in moist soils where conditions are most favorable to microbial activity. Both insecticides persisted longest in soil at the Upper Piedmont Research Station where soil moisture was higher most of the growing season. Hence, other factors probably contributed to the difference.

In leaf samples from the first harvest at Reidsville, ethoprop residues were 0.20 and $0.27 \mathrm{ppm}$, respectively, for the 6.72 and $13.4 \mathrm{~kg} / \mathrm{ha}$ rate (Table 6). Residues declined in each successive harvest, and in fifth-priming samples concentrations were less than $0.01 \mathrm{ppm}$. Levels of ethoprop in leaf samples from the Clayton test were much lower than those in samples from Reidsville. Values for the 6.72 and $13.4 \mathrm{~kg} / \mathrm{ha}$ rate at Clayton averaged only 22 and $36 \%$, respectively of the corresponding values for Reidsville.

Residues of ethoprop from the $6.72 \mathrm{~kg} / \mathrm{ha}$ rate were less than $0.05 \mathrm{ppm}$ when averaged over all samplings and locations. Therefore, average residues from ethoprop applied at the recommended rate approached the low limit of detection ( $0.01 \mathrm{ppm}$ ), and the pesticide probably would not be detectable in tobacco products.

Disulfoton residues varied widely among leaf samples from different locations, rates of application, and harvest dates. Residues from the $3.4 \mathrm{~kg} / \mathrm{ha}$ rate applied alone or in combination with ethoprop were higher than those from the $6.7 \mathrm{~kg} / \mathrm{ha}$ rate applied alone in several samplings (Table 7). We have no good explanation for this variation. Perhaps the broadcast application, the incorporation by disking, and the bedding operation produced uneven distribution in the beds and, hence, led to variation in the exposure of the tobacco roots to the chemical.

Residues of the metabolite, disulfoton sulfone, were higher than those for the parent compound, disulfoton, and the other metabolites, averaging $6.37 \mathrm{ppm}$ in samples from Reidsville and $1.65 \mathrm{ppm}$ in samples from Clayton for the first harvest at the $3.4 \mathrm{~kg} / \mathrm{ha}$ rate. When total residues were compared between locations, those from the Upper Piedmont Station were highest. Our values for Reidsville samples were similar in magnitude to those obtained by Bowman et al. (4).

Total residues of disulfoton were found in much higher amounts in tobacco leaf than residues of ethoprop, suggesting that it, in comparison to ethoprop, is absorbed more readily by tobacco plants, is more persistent in plants, or is affected less during curing than ethoprop is. 
Table 6. Ethoprop residues (at $13 \%$ molsture) In flue-cured tobacco from two locations.

\begin{tabular}{|c|c|c|c|c|c|c|}
\hline \multirow{2}{*}{ Location } & \multirow{2}{*}{$\begin{array}{c}\text { Rate } \\
(\mathrm{kg} / \mathrm{ha})\end{array}$} & \multicolumn{5}{|c|}{ Harvest number * } \\
\hline & & $\begin{array}{c}1 \\
\text { (ppm) }\end{array}$ & $\stackrel{2}{2}$ & $\begin{array}{c}3 \\
(\mathrm{ppm})\end{array}$ & $\begin{array}{c}4 \\
(\mathrm{ppm})\end{array}$ & $\begin{array}{c}5 \\
(\mathrm{ppm})\end{array}$ \\
\hline Central Crops Research Station & 0.0 & 0.03 & $<0.01$ & $<0.01$ & $<0.01$ & \\
\hline \multirow[t]{3}{*}{ (Clayton, N.C.) } & 6.72 & 0.04 & 0.01 & 0.01 & 0.01 & \\
\hline & 13.4 & 0.08 & 0.05 & 0.03 & 0.03 & \\
\hline & $6.72^{* *}$ & 0.02 & 0.02 & 0.02 & 0.02 & \\
\hline Upper Piedmont Research Station & 0.0 & 0.09 & 0.06 & 0.04 & 0.02 & $<0.01$ \\
\hline \multirow[t]{3}{*}{ (Reidsville, N.C.) } & 6.72 & 0.20 & 0.09 & 0.05 & 0.04 & $<0.01$ \\
\hline & 13.4 & 0.27 & 0.17 & 0.06 & 0.04 & $<0.01$ \\
\hline & 6.72 & 0.16 & 0.09 & 0.07 & 0.03 & $<0.01$ \\
\hline
\end{tabular}

- Each value an average of four replications. Tobacco harvested July 15, July 23, August 5, and August 20,1976 at Central Crops Research Station. Tobacco harvested July 22, August 10, August 23, September 8, and September 13, 1976 at Upper Pledmont Research Station.

** Combination treatment with disulfoton.

Table 7. Residues of dlsulfoton and three metabolites in flue-cured tobacco from Central Crops (Clayton) and Upper Pledmont (Reidsville) Research Statlons.

\begin{tabular}{|c|c|c|c|c|c|c|c|}
\hline \multirow{2}{*}{ Location } & \multirow{2}{*}{ Disulfoton or metabolite } & \multirow{2}{*}{$\begin{array}{c}\text { Rate } \\
\text { (kg/ha) }\end{array}$} & \multicolumn{5}{|c|}{ Harvest number * } \\
\hline & & & $\begin{array}{c}1 \\
(\mathrm{ppm})\end{array}$ & $\begin{array}{c}2 \\
(\mathrm{ppm})\end{array}$ & $\begin{array}{c}3 \\
(\mathrm{ppm})\end{array}$ & $\begin{array}{c}4 \\
(\mathrm{ppm})\end{array}$ & $\begin{array}{c}5 \\
(\mathrm{ppm})\end{array}$ \\
\hline \multirow[t]{12}{*}{ Central Crops } & Disulfoton & 3.4 & 0.04 & 0.02 & 0.06 & 0.02 & \\
\hline & & 6.7 & 0.04 & 0.02 & $<0.01$ & $<0.01$ & \\
\hline & & $3.4 * *$ & 0.09 & 0.01 & $<0.01$ & $<0.01$ & \\
\hline & Disulfoton oxygen analog & 3.4 & 0.04 & 0.03 & 0.07 & 0.02 & \\
\hline & & 6.7 & 0.05 & 0.03 & $<0.01$ & $<0.01$ & \\
\hline & & $3.4^{* \star}$ & 0.05 & 0.02 & $<0.01$ & $<0.01$ & \\
\hline & Disulfoton sulfoxide oxygen analog & 3.4 & 0.81 & 0.14 & 0.96 & 0.03 & \\
\hline & & 6.7 & 0.46 & 0.32 & 0.17 & $<0.01$ & \\
\hline & & $3.4^{* *}$ & 0.84 & 0.23 & 0.12 & 0.01 & \\
\hline & Disulfoton sulfone & 3.4 & 1.65 & 0.46 & 0.38 & 0.04 & \\
\hline & & 6.7 & 1.34 & 1.18 & 0.31 & 0.06 & \\
\hline & & $3.4 * *$ & 1.21 & 0.87 & 0.34 & 0.12 & \\
\hline \multirow[t]{12}{*}{ Upper Piedmont } & Disulfoton & 3.4 & 0.05 & 0.02 & $<0.01$ & 0.04 & 0.02 \\
\hline & & 6.7 & 0.20 & 0.16 & 0.03 & 0.02 & $<0.01$ \\
\hline & & $3.4^{* *}$ & 0.05 & 0.03 & 0.01 & $<0.01$ & $<0.01$ \\
\hline & Disulfoton oxygen analog & 3.4 & 0.26 & 0.20 & 0.06 & 0.07 & 0.03 \\
\hline & & 6.7 & 0.14 & 0.15 & 0.03 & 0.02 & $<0.01$ \\
\hline & & $3.4^{* *}$ & 0.05 & 0.02 & 0.01 & $<0.01$ & $<0.01$ \\
\hline & Disulfoton sulfoxide oxygen analog & 3.4 & 3.57 & 2.97 & 1.05 & 0.14 & $<0.01$ \\
\hline & & 6.7 & 0.61 & 0.31 & $<0.01$ & $<0.01$ & $<0.01$ \\
\hline & & $3.4^{* *}$ & 0.71 & 0.57 & $<0.01$ & $<0.01$ & $<0.01$ \\
\hline & Disulfoton sulfone & 3.4 & 6.37 & 5.05 & 1.06 & 0.60 & 0.02 \\
\hline & & 6.7 & 5.54 & 4.91 & 0.16 & 0.08 & $<0.01$ \\
\hline & & $3.4^{* *}$ & 2.76 & 1.39 & 0.77 & 0.27 & $<0.01$ \\
\hline
\end{tabular}

- Each value en average of four replications. Residues of disulfoton sulfoxide and disulfoton sulfone oxygen analog were below the detectable Iimit of 0.01 ppm. Tobacco harvested July 15, July 23, August 5, and August 20, 1976 at Central Crops Research Station. Tobacco harvested July 22, August 10, August 23, September 8, and September 13, 1976 at Upper Pledmont Research Station.

** Combination treatment with ethoprop. 
Soil samples collected approximately 21 days after pretransplant applications of ethoprop to flue-cured tobacco land contained residues averaging 0.54 and $1.13 \mathrm{pPm}$, respectively, for the 6.7 and $13.4 \mathrm{~kg} / \mathrm{ha}$ rates. In contrast total residues of disulfoton (disulfoton plus three metabolites) averaged 0.28 and $0.54 \mathrm{ppm}$ at 3.4 and $6.7 \mathrm{~kg} / \mathrm{ha}$ rates. Concentrations of both compounds decreased with time at each of two locations. Residue levels of ethoprop in the first harvest of flue-cured tobacco from the Central Crops Research Station (Clayton, North Carolina) were 0.04, 0.02, and $0.08 \mathrm{ppm}$; from the Upper Piedmont Research Station (Reidsville, North Carolina), residues were $0.20,0.16$, and $0.27 \mathrm{ppm}$, respectively, for rates of $6.7,6.7$ combination (with disulfoton), and $13.4 \mathrm{~kg} / \mathrm{ha}$. Residues declined in succeeding harvests. Total residues of disulfoton plus three metabolites in the first sample of tobacco harvested from Central Crops averaged 2.52 and $1.89 \mathrm{ppm}$; and from Upper Piedmont residues averaged 10.24 and $6.50 \mathrm{ppm}$, respectively, for rates of 3.4 and 6.7 $\mathrm{kg} / \mathrm{ha}$. The residues declined in succeeding harvest and were $0.14 \mathrm{ppm}$ or less by the fourth harvest at Central Crops and $0.08 \mathrm{ppm}$ or less by the fifth harvest at Upper Piedmont.

\section{ZUSAMMENFASSUNG}

Etwa 21 Tage nach Applikation von Ethoprop in Mengen von $6,7 \mathrm{~kg}$ und $13,4 \mathrm{~kg}$ je ha vor dem Auspflanzen der Setzlinge ("flue-cured") wiesen Bodenproben durchschnittlich Rückstände von $0,54 \mathrm{ppm}$ bzw. 1,13 ppm auf. Die Gesamtrückstände im Boden an Disulfoton einschließlich 3 Metaboliten beliefen sich dagegen im Durchschnitt bei Gaben von $3,4 \mathrm{~kg}$ und $6,7 \mathrm{~kg}$ je ha auf $0,28 \mathrm{ppm}$ bzw. 0,54 ppm. An zwei Versuchsorten zeigte sich gleichermaßen ein Rüdkgang der Konzentration beider Verbindungen im Boden mit fortschreitender Zeit. Bei Gaben von $6,7 \mathrm{~kg}$ Ethoprop, 6,7 kg Ethoprop in Verbindung mit Disulfoton und 13,4 kg Ethoprop je ha machten die Rückstände im "flue-cured"-Tabak bei der ersten Ernte in Central Crops Research Station, Clayton, N.C., 0,04, 0,02 bzw. 0,08 ppm und in Upper Piedmont Research Station, Reidsville, N.C., $0,20,0,16$ bzw. 0,27 ppm aus. Die Rückstandsmengen gingen in den nachfolgenden Ernten zurüd. Nach Applikation von 3,4 kg und 6,7 kg Disulfoton je ha zeigten die Tabakproben bei der ersten Ernte Gesamtrückstände an Disulfoton einschließlich 3 Metaboliten von durchschnittlich 2,52 ppm bzw. 1,89 ppm in Clayton und 10,24 ppm bzw. 6,50 ppm in Reidsville. Die Rüdkstände nahmen bei den folgenden Ernten ab und betrugen in Clayton bei der vierten Ernte 0,14 ppm und weniger und in Reidsville bei der fünften Ernte 0,08 ppm und weniger.
Des échantillons de terre, prélevés environ 21 jours après le traitement à l'éthoprop précédant la transplantation du tabac «flue-cured et effectué à raison de 6,7 et $13,4 \mathrm{~kg}$ par hectare, ont présenté des quantités moyennes de résidus de 0,54 ppm et $1,13 \mathrm{ppm}$ respectivement. Comparativement, les résidus totaux de disulfoton (y compris 3 métabolites) atteignaient, après une application de 3,4 et $6,7 \mathrm{~kg}$ par hectare, une moyenne de 0,28 et $0,54 \mathrm{ppm}$ respectivement. On a constaté une diminution de la concentration des deux composés dans le sol, en fonction du temps, dans deux centres de recherche. Après des traitements comprenant 6,7 kg d'éthoprop, une combinaison de $6,7 \mathrm{~kg}$ d'éthoprop et de disulfoton et $13,4 \mathrm{~kg}$ d'éthoprop par hectare, les résidus dans le tabac «flue-cured» de la première récolte atteignaient $0,04,0,02$ et $0,08 \mathrm{ppm}$ respectivement aे la Central Crops Research Station, Clayton, N. C., et 0,20, 0,16 et 0,27 ppm à la $U$ pper Piedmont Researdo Station, Reidsville, N. C. Les résidus ont diminué lors des récoltes subséquentes. A la suite d'applications de 3,4 kg et de $6,7 \mathrm{~kg}$ de disulfoton par hectare, les échantillons de tabac de la première récolte contenaient en moyenne des résidus totaux de disulfoton (y compris 3 métabolites) de $2,52 \mathrm{ppm}$ et $1,89 \mathrm{ppm}$ respectivement à Clayton et de 10,24 ppm et 6,50 ppm d Reidsville. Les résidus ont diminué lors de récoltes subséquentes. A Clayton, ils atteignaient $0,14 \mathrm{ppm}$ et moins lors de la quatrième récolte, à Reidsville, $0,08 \mathrm{ppm}$ et moins à la cinquième récolte.

\section{REFERENCES}

1. Kearney, P. C., E. A. Woolson, J. R. Plimmer and A. R. Isensee: Res. Rev. 29 (1969) 137.

2. Clapp, D. W., D. V. Naylor and C. G. Lewis: J. Environ. Quality. 5 (1976) 207.

3. Metcalf, R. L., T. R. Fukuto and R. B. Mard: J. Econ. Entomol. 50 (1957) 338.

4. Bowman, M. C., M. Beroza and C. R. Gentry: J. Ass. Offic. Anal. Chem. 52 (1969) 157.

5. Wittekindt, W.: Personal communication, 1975 (Verband der Cigarettenindustrie, Hamburg).

Authors' address:

North Carolina State University, School of Agriculture and Life Sciences, Department of Entomology, Pesticide Residue Research Laboratory, Box 5215, ZIP 27650, Raleigh, North Carolina, U.S.A. 